\title{
Co czyni wystawa? Praktyki artystyczne kreujące „trzecią sferę”, czyli wystawianie naturykultury w galeriach sztuki ${ }^{1}$
}

Cóż może oznaczać fraza — „wystawianie naturykultury”? Jak można rozumieć zespolenie dwóch terminów zwyczajowo uznawanych za opozycyjne? I wreszcie — „co czyni wystawa?”. Niniejszy tekst jest próbą antropologicznej refleksji na tymi pytaniami.

W pierwszej części tekstu zamierzam rozważyć rzecz wystawianą, czyli co się wystawia. W kręgu moich zainteresowań w tym przypadku są wytwory artystyczne konstruujące pewne światy estetyczne, których podstawowym paradygmatem nie jest już opozycja natura/kultura. Warto podkreślić, że owe kreacje estetyczne można odnieść do mechanizmów ustanawiania relacji pomiędzy ludźmi i innymi istotami czy też różnorodnych działań artystycznych i ogólnie działań człowieka, stwarzających miejsca wspólnego osadzenia w świecie ludzi i nie-ludzi. Formowana jest w ten sposób „trzecia sfera”, połączenie kulturowo ukonstytuowanego przeciwstawienia natury i kultury, a ta sfera jest swoistą syntezą — naturokulturą. Fundament pojęcia naturykultury stanowi przekonanie o komplementarności natury i kultu-

\footnotetext{
${ }^{1}$ Pytanie „co czyni wystawa?” zadała Katarzyna Barańska w tekście Co wystawę czyni? Co czyni wystawa? [w:] Sacrum i sztuka. Życie i sztuka, red. B. Major, J. Matyja, Częstochowa: Miejska Galeria Sztuki 2004, s. 283-329. Niniejszy tekst jest rozszerzoną wersją mojego wystąpienia na konferencji Etnografia współczesności. Obszary, metody, perspektywy, zorganizowanej przez Polskie Towarzystwo Ludoznawcze i Wydział Filozoficzno-Historyczny Uniwersytetu Łódzkiego, Łódź 20-21 września 2018 r.
} 
ry, miejsce opozycji zajmuje ekologiczna relacja czynników biologicznych i społecznych [Haraway 2003, Malone and Ovenden 2017]. Owe kreacje estetyczne pozwalają również na przyjrzenie się mechanizmom wytwarzania i/ lub modyfikacji rzeczywistości i tożsamości hybrydycznych, i ich percepcji nie tylko w świecie artystycznym, ale także w odniesieniu do problemów związanych na przykład z możliwościami biotechnologii.

Nurt w sztuce, do którego się odnoszę, nie tworzy jednolitego kierunku, a jest raczej mozaiką różnorodnych działań artystycznych podejmowanych w ramach „trzeciej sfery”. Na potrzeby tego tekstu wprowadzam podział tych działań na trzy grupy, a mianowicie: działania artystyczne dekonstruujące postawy antropocentryczne; działania artystyczne ucieleśniające hybrydyczne tożsamości; działania artystyczne określane jako bio-art. Podkreślam jednak, że nie jest to podział bezwzględny, lecz porządkujący, mający na celu przedstawienie zjawiska w miarę uporządkowany sposób. Do zilustrowania każdej grupy wybrałam dzieła, które w najwyższym stopniu, moim zdaniem, oddają jej specyfikę.

\section{Działania artystyczne dekonstruujące postawy antropocentryczne oraz inicjujące dzieła, określane jako permanentny proces tworzenia i/lub dzieła współtworzone przez ludzi i inne istoty}

Do tej klasy dzieł można zaliczyć instalację Natalii Jeremijenko Tree Logic (1999). Artystka umieściła drzewa w donicach, które następnie zawiesiła nad ulicą, ale w ten sposób, że rośliny były skierowane w dół. Drzewa pomimo nakazanego przez człowieka kierunku wzrastały do góry, tworząc nietypowe kształty². Na uwagę zasługuje także projekt skandynawskiego artysty Sama Emmersona Świat widziany oczami zwierząt (2003). Emmerson umieszczał na ciałach zwierząt (między innymi wilka i mola) kamery, rejestrujące ich rozliczne aktywności, ścieżki, którymi te istoty się poruszały. Powstało w ten sposób dzieło-video.

Większość dzieł w pewien sposób wpisujących się do tej grupy powstało w kontekście rozlicznych koncepcji, u podstaw których leży przekonanie, iż wytwór artystyczny nie jest zamkniętą, skończoną formą. Z tego punku widzenia, na przykład rzeźba czy instalacja aktywują rozmaite siły, współdziałające i wzajemnie na siebie oddziałujące, i tym samym spra-

\footnotetext{
${ }^{2}$ Fotografia dzieła Natalii Jeremijenko znajduje się: https://massmoca.org/event/natalie-je remijenko.
} 
wiające, że wytwór niejako sam się wytwarza w ciągłym przekraczaniu pierwotnych warunków swojego istnienia. Przykładem jest tutaj instalacja Stitching Time ${ }^{3}$ autorstwa Erin Manning (2012). Artystka w ten sposób opisuje swoje dzieło: ,jest to rozległa instalacja stworzona z tekstylnej kolekcji nazwanej Folds to infinity. Stitching Time była rozumiana jako dzieło uwarunkowane miejscem, które usiłowało wprowadzić w relacyjną grę zarówno środowiskowe aspekty, jak i te odzieżowe połączenia z Folds to infinity" [Manning 2015: 52].

Na Folds to infinity składają się duże kawałki materiału zaopatrzone w magnesy, zatrzaski, guziki i dziurki - umożliwia to tworzenie swojego rodzaju ubiorów. Artystka rozwiesza materie w określanych konfiguracjach, do tworzenia dzieła zapraszając również widzów. W Stitching Time te „ubrania” artystka umieściła na rozciągniętej sieci. Według Manning, kompozycja przez nią stworzona podlega ciągłej metamorfozie pod wpływem otoczenia. Uważa ona, iż dzieło winno być przede wszystkim sposobem włączenia wszystkich swoich czynników w ruch relacyjny, uruchamia się wówczas

moc stawania się, która jest tworzeniem ekologii, ekologii nigdy niedającej się podporządkować artyście lub indywidualnemu uczestnikowi. [...] Wszystkie ekologie są więcej niż ludzkie. One są zarówno oddechem ruchu, jak i migotaniem światła i dźwiękiem wyciszenia. Są ziemią i fakturą, powietrzem i wiatrem, kolorem i nasyceniem" [Manning 2015: 63].

\section{Działania artystyczne ucieleśniające hybrydyczne tożsamości}

W tej grupie umieściłam te działania, które za pomocą rozmaitych technik artystycznych kreują obraz swojego rodzaju melanżu cech fizycznych, między innymi człowieka/zwierzęcia, człowieka/rośliny. Można tu wymienić jako przykład cykl fotografii-portretów Nancy Burson. Serie te powstają od lat 80., jednym z bardziej znanych zdjęć jest wizerunek twarzy/pyska ludzko-małpiego ${ }^{4}$. Egzemplifikacją wizji hybrydycznej tożsamości jest również dzieło Patrici Piccinini The Young Family $(2002)^{5}$ — sylikonowa

\footnotetext{
${ }^{3}$ Fotografia dzieła Erin Manning znajduje się: http://erinmovement.com/stitching-time.

${ }^{4}$ Fotografie dzieł Nancy Burson znajdują się: https://www.nancyburson.com/portfolio/ G0000llUHNPmgqZs; https://www.mutualart.com/Artwork/Evolution-II/FE05524B7559FE16.

${ }^{5}$ Fotografie dzieł Patrici Piccinini znajdują się: https://www.artsy.net/artwork/patricia-picci nini-the-young-family-1.
} 
rzeźba będąca zbiorowym portretem matki i dzieci; wszystkie postaci mają kształt zwierzęco-ludzki.

W kontekście wytwarzania dzieł obrazujących hybrydyczne tożsamości ukazuje się ciekawy problem, a mianowicie kwestia użycia i transformacji funkcjonujących w zbiorowej pamięci obrazów-symboli człowieka/ zwierzęcia. Otóż te przedstawienia obrazowe, które w kulturze europejskiej były ekspresją monstrualności, stają się w ostatnich latach wyrazem czegoś pozytywnego - zwierzęco/ludzkiej tożsamości rozumianej jako konglomerat wielu zmiennych.

\section{Działania artystyczne określane jako bio-art}

W tym nurcie działanie artystyczne polega na manipulacji biologicznym i genetycznym materiałem, kreuje się lub wykorzystuje transgenetyczne organizmy, które są wystawiane jako dzieła sztuki. Chyba najbardziej znanym „obiektem” jest tutaj królik, GFP Bunny (2000) Eduarda Kaca6. Wśród tego rodzaju praktyk artystycznych wymienić można także pracę polskiej artystki Karoliny Żyniewicz pod tytułem Ostatnia wieczerza ${ }^{7}$. Egzemplifikacją bio-artu jest również projekt Any Karle — ręka z biodegenerowanego materiału (odpadki chirurgiczne), wydrukowana następnie w drukarce 3D umieszczona została w specjalnym pojemniku. W ten sposób przygotowane „rusztowanie” obrastało ludzkimi komórkami macierzystymi, które następnie przekształcają się w różne tkanki ręki .

Dla antropologa jednym z ciekawych problemów w kontekście bio-artu jest zagadnienie zastosowania narzędzi biotechnologicznych - na przykład badań nad kodem genetycznym - w polu działań artystycznych. W związku z tego rodzaju praktykami, rozważyć można kwestię figury artysty, a mianowicie, czy kreowany jest tutaj wizerunek artysty jako postaci mającej moc dotykania i manipulowania bytem — dzieło w tym przypadku może być bowiem odbierane jako rzeczywistość sama, a nie jej reprezentacja.

\footnotetext{
${ }^{6}$ Fotografia dzieła Eduarda Kaca znajduje się: https://www.ekac.org/gfpbunny.html\#gfpbun nyanchor.

${ }^{7}$ Fotografia dzieła Karoliny Żyniewicz znajduje się: http://karolinazyniewicz.com/gallery-cate gory/living-projects/\#the-last-supper.

${ }^{8}$ Fotografia dzieła Any Karle: https://www.polityka.pl/tygodnikpolityka/nauka/1762498,1, fascynujacy-bioart-czyli-fuzja-sztuki-i-nauki.read.
} 
Tego rodzaju działania artystyczne, których egzemplifikacje przedstawiłam, można potraktować jako wyraz poszukiwania i prezentacji nowej figuracji najistotniejszych współczesnych problemów. Owa potrzeba nowych ekspresji jest zaś konsekwencją podważenia paradygmatu leżącego u podstaw humanizmu i tym samym twierdzeń o centralnej pośród bytu pozycji człowieka. Według badaczy wywodzących się z nurtu posthumanizmu/postantropocentryzmu, humanizm jako ideał cywilizacyjny z roszczeniem do uniwersalizmu okazał się konstruktem, który stracił już swoją aktualność. Uważają oni, iż ta konstrukcja została skonfigurowana na fundamencie binarnej logiki tożsamości i wykluczenia, swego rodzaju machiny antropologicznej [Agamben 2004: 33-39]. Machina ta, poprzez różnicowanie, wytwarza kategorie tego, co ludzkie i tego, co nie-ludzkie. Podważenie antropocentryzmu otworzyło horyzonty dla nowych epistemologii, nowych pytań. Niewątpliwie tworzą one nową interdyscyplinarną przestrzeń naukową obejmującą nauki humanistyczne, nauki społeczne, biologię, biotechnologię. W owej przestrzeni możemy odnaleźć szereg nurtów, rozmaite punkty widzenia. Chcę w skrócie w tym miejscu zwrócić uwagę na dwie tendencje.

Pierwszą tendencję stanowi tzw. posthumanizm. Kierunek ten posiada charakter witalistyczny, proponuje - jak stwierdza Agata Bielik-Robson swego rodzaju powrót do natury [Bielik-Robson 2014]. Natura rozumiana jest tutaj w wymiarze biologicznym, jako nagie, wegetatywne życie - zoe, w całej swojej potencjalności stawania się i zamierania. Według jednej z głównych teoretyczek tego trendu, Rosi Braidotti, zoe jest materialistyczną siłą, twórczą mocą przepływającą przez wszystkie gatunki. Takie ujęcie życia pozwala na transwersalny sojusz pomiędzy gatunkami i budowanie podmiotowości zupełnie odmiennej niż podmiotowość humanistyczna i antropocentryczna. Podmiotowość posthumanistyczna nie stanowi stałej, zamkniętej całości, ale jest ciągłym ruchem, stawaniem się czy wzrastaniem w rozlicznych hybrydycznych konfiguracjach. Wymienia się trzy podstawowe kierunki permanentnej transformacji: 1) stawanie się ziemią; 2) stawanie się zwierzęciem; 3) stawanie się maszyną. Nie mówi się już o opozycji natura/kultura, śmierć/życie i wynikających z nich rozlicznych innych dystynkcjach, ale mamy do czynienia z kontinuum naturakultura, życieśmierć, gdzie bios jest czasową, płynną konfiguracją. Człowiek jawi się tutaj jako odkrywająca się na nowo istota, fundamentalnie różna od podmiotowości humanistycznej. Celowo zmienia on ciało i jego rozwój 
przez wymianę genów czy organów zarówno z przedstawicielami swojego gatunku, jak i innymi organizmami [Braidotti 2013]. Sztuka, której praktyki rozwijają się w takich ramach referencyjnych, jest uważana przez teoretyków i praktyków za pole badawcze i eksperymentalne różnorodnych stylizacji. Na gruncie polskim Monika Bakke zaproponowała objęcie tego bardzo różnorodnego nurtu mianem zoe-estetyki. Według autorki, zoe-estetyka może stać się użytecznym narzędziem badawczym służącym do zrozumienia doświadczenia estetycznego również poza dziedzinami artystycznymi, „dla których kluczowe znaczenie ma życie jako takie, materialna witalność, transgatunkowe relacje zakorzenione w środowisku lub biotechnologie" [Bakke 2012: 232].

Drugą tendencję określa się jako nurt ekologiczny. W tymże nurcie ukazuje się zjawisko, którego istotę możemy odnaleźć w bogactwie znaczeniowym greckiego terminu oikos, od niego zresztą pochodzi pojęcie „ekologia”. Oikos to dom, budowla, ale również rodzina, a według Arystotelesa - żyjący w domu, czyli najbliższe otoczenie, w którym wytwarza się relacja ja-ty, a dzięki temu powstaje wspólnota rozlicznych podmiotowych relacji. Można stwierdzić, iż postawy artystyczne w nurcie ekologicznym formują działania artystyczne, których celem jest przywrócenie pojęciu „zamieszkiwania” znaczenia środowiska jako domu. Wówczas metamorfozie ulega spojrzenie na świat - z panoramicznego, zdystansowanego, syntetyzującego zamienia się w uważność na szczegół, „patrzenie” z bliska. Dąży się do szczególnego rodzaju sprzężenia widzenia, słyszenia, dotykania, wąchania i smakowania. Już nie bada się i ogląda świat, ale jest się w środowisku, współtworzy wspólne relacje na styku człowiek/przyroda.

Na zadane na wstępie pytanie o rzecz wystawianą, czyli co, w tym momencie można odpowiedzieć, iż wystawiane są wytwory artystyczne, które powstają w kontekście kwestionowania antropocentryzmu. Praktyki artystyczne ucieleśniają w tych sytuacjach swoistą „trzecią sferę” - naturękulturę, podważając czy niwelując tym samym opozycję natura/kultura. Niewątpliwie antropologiczna eksploracja winna objąć te praktyki artystyczne, tym bardziej, że podważenie antropocentryzmu otworzyło horyzonty dla nowych epistemologii, nowych pytań. Niewątpliwie tworzą one nową interdyscyplinarną przestrzeń naukową obejmującą nauki humanistyczne, nauki społeczne, biologię, biotechnologię. Istotny wkład w dyskutowane zagadnienia wnosi refleksja antropologiczna, by wymienić między innymi antropologię międzygatunkową, antropologię na granicy, 
anthropology of the edge (termin użyty przez Kirsten Hastrup, 2014) czy antropologię ekologiczną. Badacze reprezentujący te trendy podkreślają, iż antropologia nie ogranicza się jedynie do ludzi, ale jest zainteresowana efektami powiązań człowieka z innymi rodzajami żyjących istot. Hastrup uznaje, że w tym sensie eksploracja antropologiczna jest rodzajem eksperymentowania w świecie, który nie jest ani społeczny, ani naturalny, ale wynika z wielu połączeń, które dopiero zaczynamy rozumieć i które wymagają konceptualizacji [Hastrup 2014: 1-26]. Na gruncie antropologii ekologicznej badacze często odwołują się do działań artystycznych lub też współpracują z artystami, traktując sztukę jako miejsce nowych figuracji współgrających z ustaleniami teoretyków. Sztandarowym teoretykiem jest tutaj Tim Ingold, który odnajduje korespondencję między badaniem antropologicznym a praktyką artystyczną w sposobie poznawania świata, co oznacza przede wszystkim badanie jako empiryczne studiowanie świata/ materiału, „bycie w nim”, a nie jedynie zdystansowany, obiektywizujący ogląd [Ingold 2013: 1-17]. Kirsten Hastrup pisząc o konieczności refleksji antropologicznej nad wyłaniającą się „trzecią sferą”, przywołała w pewnym monecie rozważania Thomasa Kuhna o przewrocie kopernikańskim, jego znaczeniu dla rewolucji naukowej. Otóż zdaniem Kuhna, owego przewrotu nie wywołały nowe odkrycia astronomiczne, natomiast był on konsekwencją nowatorskich, ugruntowanych w renesansowym widzeniu świata, sposobów rozumienia starych odkryć. Hastrup stwierdza więc:

W antropologii w ciągu ostatnich dwudziestu lat trudno odnaleźć nowe odkrycia, zaś te, już istniejące, zostały zrekonstruowane w odpowiedzi na historyczny i naukowy rozwój świata — do którego antropologia też wniosła wkład przez poszukiwanie nowych sposobów jego ujęcia” [Hastrup 2013: 4].

Sztuka posthumanistyczna oraz ekologiczna jest zbiorem różnorodnych praktyk, tekstów i przedmiotów, których nie da się sprowadzić jedynie do zagadnień związanych z artystycznym polem eksperymentalnym, zasadne natomiast wydaje się rozpatrywanie tych działań jako kreacji pewnych światów estetycznych, jednak nie sposób tego dokonać bez ogólniejszego ujęcia antropologicznego. Z perspektywy antropologicznej bowiem wytwory artystyczne, które są poszukiwaniem nowych ekspresji kreują tym samym nowe relacje, ewokują „trzecią sferę”. Powinno się je traktować jako manifestacje działań artystycznych, będących szczególnym rodzajem praktyk społeczno-kulturowych w świecie, z którym są związane. Wytwory artystyczne nie 
stanowią zamkniętych całości, lecz są każdorazowo zdarzeniem i kreują zdarzenie. Dzieła potraktowane są więc w takim ujęciu jako podmioty posiadające zdolność działania i wywoływania określonych efektów. W tych aspektach rozumienie wytworu artystycznego jest zbieżne z koncepcjami wypracowanymi w ramach antropologii sztuki - chcę tu przywołać teorię Alfreda Gella, wyłożoną przede wszystkim w książce Art and Agency [1998]. Janusz Barański zwraca uwagę, iż „Gell widzi [...] sztukę przede wszystkim jako sferę działania, dziedzinę zmieniającą świat, a nie jedynie mówiącą coś o nim, wpływającą przy tym na ludzkie myśli i czyny” [Barański 2017: 165]. Teoria angielskiego antropologa została wypracowana w celu zrozumienia sztuki pozaeuropejskiej bez redukcjonistycznego, europocentrycznego punktu widzenia, natomiast zawarte w niej narzędzia heurystyczne mogą być stosowane do analizy wytworów estetycznych zarówno tak zwanej sztuki wysokiej, jak i na przykład sztuki popularnej. Gell definiuje sztukę jako szczególny sposobu działania wytwarzający konfigurację społecznych powiązań. Wytwór w tej wykładni jest swojego rodzaju centrum ewokującym zależności przyczynowo-skutkowe. Owa sieć relacji — sieć sztuki — splata ze sobą dzieło/indeks, wytwórcę, odbiorcę i prototyp, który „indeks reprezentuje wizualnie lub nie-wizualnie" [Gell 1998: 28].

Gell wywodzi rozumienie indeksu z semiotyki Charlsa Sandersa Peirce'a. Amerykański filozof kategoryzował znaki na podstawie trzech kryteriów. W tym przypadku interesująca jest dla nas ta podstawa wyróżnienia, którą jest rodzaj relacji łączącej znak z przedmiotem oznaczanym. Do tej klasy znaków należą ikony, indeksy właśnie i symbole. Otóż, relacja łącząca indeksy z przedmiotami oznaczanymi, tak zwana relacja indeksalna, istnieje o tyle, o ile odnosi nas do konkretnego doświadczenia lub do czegoś z czym „jesteśmy zaznajomieni przez działanie tego czegoś na nas, lub nasze działanie na to coś [...]. [Indeksy - B.M.] oznaczają swoje przedmioty na mocy rzeczywistego, przyczynowego połączenia” [Peirce W4:250]. Peirce powiada również, iż „Indeks niczego nie orzeka, on tylko mówi „oto”, „tam”, więzi nasze oczy i siłą kieruje na pojedynczy przedmiot, i tam je zatrzymuje” [Peirce W5:163]. Możemy w dużym uproszczeniu stwierdzić, że w relacji indeksalnej działają dwie siły, jedna sprawcza, wywiera nacisk, oddziałuje, wpływa, „chwyta”, druga zaś odpowiada na tę pierwszą: poddaniem się, obroną, skierowaniem uwagi, itd., natomiast ośrodkiem „przepływu” tychże sił jest indeks. Czyli indeks należy do tej klasy znaków, których natura, kształt, zachowanie itd., jest efektem działania/oddziaływania obiektu, który 
oznaczają. Ten wpływ może być przyczynowy (ogień powoduje dym, dym więc jest indeksem ognia) lub opierać się na współwystępowaniu (kwiat wpięty we włosach pięknej dziewczyny staje się znakiem pięknej dziewczyny). Należy ponownie podkreślić, iż indeksy wskazują na konkretny związek, aktualną rzecz lub działanie, czy też działanie z przeszłości, którego efekty mają moc oddziaływania tu i teraz. Mówiąc w skrócie, odniesienie znaku jest jednocześnie jego sprawcą.

W sytuacji, gdy nie jesteśmy pewni lub nie znamy sprawcy, czyli znak-indeks jest dla nas niewiadomą, doświadczamy go jako czegoś „innego”, zaburzającego nasz zwyczajny bieg spraw. Właśnie w ten sposób działają, według wykładni Gella, dzieła sztuki/indeksy, są one bowiem wynikiem i/lub instrumentem działania społecznej sprawczości, polegającej na swoistym zaczarowaniu/uwiedzeniu odbiorców. Owa fascynacja czy zdziwienie uruchamia proces wnioskowania/swoistej interpretacji, próbującej wyjaśnić kto/co jest sprawcą określonego efektu, ale odbywa się to w trybie przypuszczenia — być może? Domniemywanie źródła/sprawcy zaczarowania, jest według Gella dystynktywną właściwością praktyk artystycznych. Matthew Rampley uważa, że Gell włącza w obszar sztuki „wszystko to, co funkcjonuje jako indeks społecznej sprawczości wewnątrz «sieci sztuki»"[Rampley 2005:542]. Eric Hirsch zaś twierdzi, że cztery elementy owej „sieci sztuki”, wyszczególnione przez Gella, a mianowicie indeks/wytwór, artysta, odbiorca i prototyp są: „relacyjnym slotem wewnątrz sieci sztuki, który potencjalnie może być wypełniony przez wszystko i wszystkich. Każdy działa jak sprawca lub odbiorca naprzeciwko innych, czasami robią to jednocześnie lub w innych momentach” [Hirsch 2018: 83].

Rozpatrzmy w świetle wykładni Alfreda Gella rzeźby wystawione przez artystów Tatianę Czekalską i Leszka Golca w ramach ekspozycji Ecce animalia, prezentowanej w 2014 r. w Centrum Rzeźby Polskiej w Orońsku. Dzieło to składa się z popiersia wyobrażającego św. Franciszka, gdzie drewno, z którego wykonano rzeźbę, pełne jest dziurek (i tunelików) wydrążonych przez kołatki. Obiekt nosi tytuł Homo Anobium. Święty Franciszek 100 procent rzeźby i datowany jest na lata 1680-19859. Wyeksponowany został jako wspólna kreacja nieznanego rzeźbiarza i kołatków. Odpowiednio, pierwszy człon daty wskazuje czas wyrzeźbienia Świętego, drugi zaś jest terminem opuszczenia figury przez owady. Podążając za myślą angielskiego antro-

\footnotetext{
${ }^{9}$ Analizowane dzieło można zobaczyć: https://www.rzezba-oronsko.pl/index.php?kolekcja_ crp,38,315,golec_tatiana_czekalska_leszek\#prettyPhoto.
} 
pologa, podstawowym problemem wydaje się tutaj kwestia sprawczości. Nasuwają się pytania o to, kto jest kreatorem dzieła, a kto odbiorcą, jakie manifestują się tutaj relacje. Dziurki/tunele w rzeźbach mają wzbudzić podziw dla kreatywności owadów (np. stają się efektami twórczej mocy tych stworzeń), a nie złość z powodu zniszczenia wizerunków Świętego (przestają być w tych relacjach indeksami destrukcyjnego działania). Rzeźby wystawiono w galerii sztuki, a w następstwie tego wytworzono pewne relacje wzajemnie się warunkujące, między innymi relację indeksalną. Owo powiązanie powstało przez współobecność instalacji i sali wystawowej, a tym samym rzeźby stały się pełnowartościowymi obiektami artystycznymi - indeksami sztuki. Na podobne związki wskazuje instytucjonalna definicja sztuki, według niej bowiem dzieło nie istnieje bez sali wystawowej, ją zaś powołuje do życia wystawianie dzieł [Danto 2006: 35-47]. W ramach wystawy zaprezentowano wytwory wbrew pewnemu ususowi, ponieważ według powszechnie przyjętych kryteriów owe rzeźby są uszkodzonymi obiektami wymagającymi zabiegów konserwatorskich oraz upewnienia się, że owady przestały działać. Wystawienie tychże wytworów zawierało w sobie gest unieważnienia pewnego systemu kwalifikacji, opierającego się na antropocentryzmie, oraz stanowiło swojego rodzaju wyzwanie w odniesieniu do społecznej organizacji smaku.

„Co czyni” więc w tej sytuacji wystawa? Wystawa umiejscawia na widoku, eksponuje. Pewną wskazówką jest tutaj etymologia słowa ekspozycja: „pozycja” pochodzi od łacińskiego ponere - ustawić, położyć, „eks” zaś w tym przypadku oznacza: od-, wy-, z (czego) i jest swego rodzaju wzmocnieniem położenia. Z jednej strony, umieszczenie w sali wystawowej powoduje, iż rzeźby w takiej postaci mogą stać się indeksami świata sztuki - na zasadzie relacji współwystępowania, tym samym do Art World włącza się efekt działań nie-ludzkiego sprawcy. Z drugiej zaś strony, jako indeksy sprawstwa (wspólnego człowieka i owada) wskazują na ekologiczną wizję świata (prototyp). Wystawa staje się więc miejscem konstruowania pewnego świata estetycznego, którego podstawowym paradygmatem nie jest już opozycja natura/kultura, a owe kreacje estetyczne można odnieść do mechanizmów ustanawiania relacji pomiędzy ludźmi i innymi istotami czy sposobów, w jakie działania artystyczne stwarzają miejsca wspólnego osadzenia w świecie ludzi i nie-ludzi. Eksponuje się naturękulturę. 


\section{Bibliografia}

\section{Agamben Giorgio}

2004: The Open: Man and Animal, transl. Kelvin Attell, Stanford: Stanford University Press.

\section{Bakke Monika}

2012: Bio-transfiguracje. Sztuka i estetyka posthumanizmu, Warszawa: Wydawnictwo Naukowe PWN.

\section{Barański Janusz}

2017: Etnologia w erze postludowej. Dalsze eseje antyperyferyjne, Kraków: Wydawnictwo Uniwersytetu Jagiellońskiego.

\section{Bielik-Robson Agata}

2014: Wylewanie dziecka z kąiela, https://krytykapolityczna.pl/felietony/agata-bielik-ro bson/wylewanie-dziecka-z-kapiela/, data odczytu: 03.03.2018.

\section{Braidotti Rosi}

2013: The Posthuman, Cambridge: Polity Press.

\section{Danto Arthur C.}

2006: Świat sztuki. Pisma z filozofii sztuki, przeł. Leszek Sosnowski, Kraków: Wydawnictwo Uniwersytetu Jagiellońskiego.

\section{Gell Alfred}

1998: Art and Agency, Oxford: Clarendon Press.

\section{Haraway Donna}

2003: The Companion Species Manifesto: Dogs, People, and Significant Otherness, Chicago: Prickly Paradigm Press.

\section{Hastrup Kirsten}

2014: Nature: Anthropology on the Edge, [w:] Anthropology and Nature, ed. Kirsten Hastrup, London: Routledge.

\section{Hirsch Eric}

2018: Beauty and captivation: Fuyuge gap and Gell's anthropological theory of art, [w:] Anthropology and Beauty. From Aesthetics to Creativity, ed. Stephanie Bunn, London: Routledge.

\section{Ingold Tim}

2013: Making. Anthropology, Archeology, Art and Architecture, London: Routledge.

\section{Malone Nicholas and Ovenden Kathryn}

2017: The International Encyclopedia of Primatology, New York: John Wiley \& Sons, Inc.

\section{Manning Erin}

2015: Artfulness, [w:] The Nonhuman Turn, ed. Richard Grusin, Minnesota: University of Minnesota Press.

\section{Peirce Charles S.}

1982-2000: Writings of Charles S. Peirce: A Chronological Edition, vols. 1-6, various editors at the Peirce Edition Project, Bloomington: Indiana University Press. 


\section{Rampley Matthew}

2005: Art History and Cultural Difference: Alfred Gell's Anthropology of Art, „Art History”, vol. 28, no 4.

\section{Barbara Major}

\section{What makes an exhibition? Artistic practices that create "the third realm", that is exhibiting natureculture in art galleries}

The article is an anthropological reflexion over the activities that are connected with exhibiting in the art galleries the art created in the ecological and/or posthumanist world vision. Exhibiting such works constitutes the gesture of outlawing a certain system of qualification based on anthropocentricism and is a challenge to social idea of taste. The exhibition becomes the place of constructing an aesthetic world, the main paradigm of which is no longer defined by the opposition nature / culture. This is how the "third realm" is created: connecting the culturally constituted contradiction of nature and culture, and that realm makes the synthesis- natureculture, where the place of opposition is taken by ecological relation of biological and social factors.

Keywords: postanthropocentric art, index, indexical relation, exhibition, natureculture 